\title{
Analysis of the Factors Associated with Negative Conversion of Severe Acute Respiratory Syndrome Coronavirus 2 RNA of Coronavirus Disease 2019
}

\author{
Nan Jiang ${ }^{1}$, Yang $\mathrm{Liu}^{2}$, Bo Yang ${ }^{3}$, Zhijun $\mathrm{Li}^{2}$, Daoyuan $\mathrm{Si}^{4}$, Piyong Ma ${ }^{5}$, Jinnan Zhang ${ }^{6}$, Tianji Liu ${ }^{1}$, Qiong Yu* \\ ${ }^{1}$ Department of Emergency, China-Japan Union Hospital, Jilin University, Changchun, China; ${ }^{2}$ Department of Epidemiology and \\ Biostatistics, School of Public Health, Jilin University, Changchun, China; ${ }^{3}$ Institute of Organ Transplantation, Tongji Hospital, \\ Tongji Medical College, Huazhong University of Science and Technology, Wuhan, China; ${ }^{4}$ Department of Cardiology, China- \\ Japan Union Hospital, Jilin University, Changchun, China; ${ }^{5}$ Department of Critical Care Unit, China-Japan Union Hospital, Jilin \\ University, Changchun, China; ${ }^{6}$ Department of Neurosurgery, China-Japan Union Hospital, Jilin University, Changchun, China
}

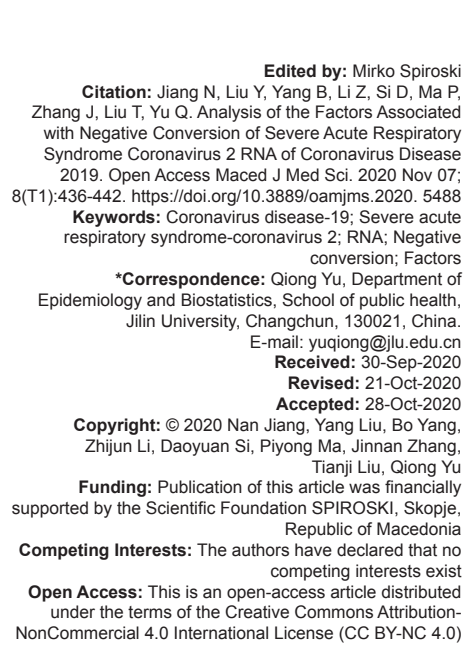

\section{Abstract}

AIM: To understand the factors associated with negative conversion of severe acute respiratory syndrome coronavirus 2 (SARS-CoV-2) RNA, targeted surveillance and control measures can be taken to provide scientific basis for the treatment of the disease and to improve the prognosis of the disease.

METHODS: Using the method of retrospective cohort study, we collected the data of Coronavirus Disease 2019 (COVID-19) patients in Tongji Hospital of Wuhan, China from 10 January to 25 March, 2020. Among the data of 282 cases, 271 patients, according to whether the negative conversion happened, were divided into negative conversion group and control group. We made the quantitative variables into classification; Chi-square test single-factor and Cox regression were used in univariate analysis and extracted 30 meaningful variables, then through the collinearity diagnosis, excluded the existence of collinear variables. Finally, 22 variables were included in Cox regression analysis.

RESULTS: The gender distribution was statistically significant between two groups $(p<0.05)$. While in the negative conversion group, the patients of non-severe group occupied a large proportion $(p<0.001)$. The median time for the negative conversion group was 17 days, and at the end of the observation period, the virus duration in control group was 24 days $(p<0.05)$. A total of 55 variables were included in univariate analysis, among which 30 variables were statistically different between the two groups. After screening variables through collinearity diagnosis, 22 variables were included in the Cox regression analysis. Last, lactate dehydrogenase (LDH), age, fibrinogen (FIB), and disease severity were associated with negative conversion of SARS-CoV-2 RNA

CONCLUSION: Our results suggest that in the treatment of COVID-19, focus on the age of more than 65 years old, severe, high level of LDH, FIB patients, and take some targeted treatment, such as controlling of inflammation, reducing organ damage, so as to provide good conditions for virus clearance in the body.

\section{Introduction}

At present, the coronavirus disease (COVID)19 has been a global outbreak, which was first reported in Wuhan, the capital of Hubei, China. A novel CoV, named severe acute respiratory syndrome CoV 2 (SARS-CoV-2) was isolated and it is the seventh member of the family of CoVs that infect humans [1]. It is so highly contagious that most individuals are susceptible to infection. As for main sources, the wild animals and infected patients are of infectiousness [2]. COVID-19 has been spread to 216 countries, areas or territories [3]. According to the latest statistics of the World Health Organization, as of July 26, 2020, more than 15,785,641 cases of the disease have been confirmed with over 640,016 deaths, making COVID-19 a major health concern [4]. Current research on COVID-19 focuses on the epidemics, its clinical features, and treatment [5]. In this case, study the factors associated with negative conversion of viral RNA is of necessary to guide the isolation precautions and antiviral treatment.

This study aims to assess the risk factors associated with prolonged viral shedding to improve treatment and prognosis of COVID-19 by considering or adjusting relative factors.

\section{Materials and Methods}

\section{Study design and data collection}

This retrospective cohort study contains a total of 282 laboratory-confirmed COVID-19 patients 
who were admitted to Tongji Hospital of Wuhan, China from 10 January to 25 March, 2020. All patients were collected throat swab samples and SARSCoV-2 RNA was detected using real-time reverse transcription polymerase chain reaction. Data of demographic characteristics, comorbidities, symptoms, and laboratory values were collected using electronic medical records. A total of 271 patients were included in the study, excluding 11 cases whose results changed repeatedly and cannot judge the time of negative conversion. Ethical Committee of Tongji Hospital of Huazhong University of Science and Technology (No. TJ-IRB20200364) and China-Japan Union Hospital of Jilin University (No.2020032607) approved the study and waived the written informed consent for rapid emerging infectious.

\section{Definitions of basic concepts}

To minimize the uncertainty of nucleic acid test, the time when a viral nucleic acid test was negative was defined as the time from the first onset of related symptoms to the time when two consecutive nucleic acid tests results were negative before discharge from the hospital, while for cases with the absence of the time of first symptom, the time of admission was replaced. If both were missing, the first sampling time was used instead. In the case of death, the time interval between the onset of symptoms and discharge was calculated without nucleic acid test data and was classified as non-negative group. Patients who returned to positive nucleic acid test after discharge and patients who were impossible to judge the time of negative conversion were excluded from the study.

\section{General conditions and laboratory test indicators}

We collected the patient's name, gender, disease severity, first symptom, basic diseases, urine routine, blood routine, erythrocyte sedimentation rate, glucose, biochemistry, coagulation, cytokines, and other indicators for the first admission test. Indicators with a missing value greater than $20 \%$ were not included in the analysis.

\section{Statistical analysis}

First, the indicators included in the analysis were analyzed by single factor analysis. According to the reference range of normal values, the quantitative variables were set as dichotomy or multiple categorization variables. Chi-square test and singlefactor Cox regression were used to compare the negative conversion group and the control group. The test level was 0.05. To reduce the influence of the inclusion of variables on the stability of the model, the missing value of variables was filled, and the mean value method was used to fill. Then, the variables whose $p$ values in the two single-factor test methods were both $<0.05$ were included in multivariate Cox regression analysis. The analysis software was IBM SPSS Statistics Version 24.0 and GraphPad Prism Version 8.2.1.

\section{Results}

\section{The basic situation}

It can be seen that the gender distribution was statistically significant between two groups $(p<0.05)$, while in the negative conversion group, the patients of non-severe disease occupied a large proportion $(78.4 \%, p<0.001)$. The median time for the negative conversion group was 17 days, and at the end of the observation period, the virus duration was 24 days ( $p$ $<0.05)$. The proportion of those older than 65 in the control group was larger $(p<0.05)$, as shown in Table 1.

\section{Single factor analysis}

Univariate analysis was performed for variables that were filled in missing values and converted into categorizing variables. A total of 55 variables were included, among which 30 variables were statistically different between the two groups, as shown in Table 1.

Then, to avoid collinearity among independent variables, which would affect the multi-factor analysis, collinearity diagnostics was made for quantitative variables with statistical significance, and the results are shown in Table 2.

As shown in Table 2, the VIF of calcium ion, $\mathrm{HCO}$, interleukin (IL)-6, PCT, AST, and IL-8 were nearly or more than 10 , which indicated the existence of collinearity. Since IL-6 and 8 had been widely reported in the previous studies [6], [7], [8], [9], [10], [11], [12], cytokine IL-10 was retained in this study to explore the influence of cytokine IL-10 on the negative transformation of COVID-19 virus. In addition, because we had enough variables, we deleted these variables as appropriate. After that, some variables were deleted because their VIF $>4$ and there were still variables of the same type. They were BU and eGFR.

After adjustment, there was no obvious collinearity between variables (Table 3). Although the VIF of TP is 3.132, we incorporated it into the analysis not to delete important variable. The screened variables were incorporated into Cox regression model for analysis. The analysis results were shown in Table 4 


\section{Table 1: Results of single factor analysis}

\begin{tabular}{|c|c|c|c|c|}
\hline \multirow[t]{2}{*}{ Variables } & \multicolumn{2}{|l|}{ Group (\%) } & $\chi^{2}$ & $p$-value \\
\hline & Control $(n=49)$ & Negative conversion $(n=222)$ & & \\
\hline Disease severit & & & & \\
\hline Non-severe & $2(4.1)$ & $174(78.4)$ & 97.324 & $<0.001$ \\
\hline Severe & $47(95.9)$ & $48(21.6)$ & & \\
\hline UPRO & & & & \\
\hline $\mathrm{N}$ & $2(4.1)$ & $108(48.6)$ & 33.062 & $<0.001$ \\
\hline $\mathrm{P}$ & $47(95.9)$ & $114(51.4)$ & & \\
\hline Gender & & & & \\
\hline Male & $33(67.3)$ & $112(50.5)$ & 4.607 & 0.032 \\
\hline Female & $16(32.7)$ & $110(49.5)$ & & \\
\hline U-KET & & & & \\
\hline $\mathrm{N}$ & $32(65.3)$ & $198(89.2)$ & 17.831 & $<0.001$ \\
\hline $\mathrm{P}$ & $17(34.7)$ & $24(10.8)$ & & \\
\hline URO & & & & \\
\hline $\mathrm{N}$ & $43(87.8)$ & $216(97.3)$ & 6.529 & 0.011 \\
\hline $\mathrm{P}$ & $6(12.2)$ & $6(2.7)$ & & \\
\hline WBC & & & & \\
\hline Normal & $17(34.7)$ & $177(79.7)$ & 48.619 & $<0.001$ \\
\hline Low & $2(4.1)$ & $12(5.4)$ & & \\
\hline High & $30(61.2)$ & $33(14.9)$ & & \\
\hline NEUT & & & & \\
\hline Normal & $11(22.4)$ & $167(75.2)$ & 58.102 & $<0.001$ \\
\hline Low & $1(2.0)$ & $10(4.5)$ & & \\
\hline High & $37(75.5)$ & $45(20.3)$ & & \\
\hline LC & & & & \\
\hline Normal & $3(6.1)$ & $109(49.1)$ & 30.575 & $<0.001$ \\
\hline Abnormal & $46(93.9)$ & $113(50.9)$ & & \\
\hline NT-PROBNP & & & & \\
\hline Normal & $8(16.3)$ & $114(51.4)$ & 19.894 & $<0.001$ \\
\hline High & $41(83.7)$ & $108(48.6)$ & & \\
\hline PCT & & & & \\
\hline Normal & $1(2.0)$ & $91(41.0)$ & 27.158 & $<0.001$ \\
\hline High & $48(98.0)$ & $131(59.0)$ & & \\
\hline Hypersensitive & & & & \\
\hline Normal & $17(34.7)$ & $170(76.6)$ & 32.921 & $<0.001$ \\
\hline High & $32(65.3)$ & $52(23.4)$ & & \\
\hline AST & & & & \\
\hline Normal & $16(32.7)$ & $162(73.0)$ & 28.950 & $<0.001$ \\
\hline High & $33(67.3)$ & $60(27.0)$ & & \\
\hline TP & & & & \\
\hline Normal & $24(49.0)$ & $183(82.4)$ & 24.902 & $<0.001$ \\
\hline Abnormal & $25(51.0)$ & $39(17.6)$ & & \\
\hline Albumin & & & & \\
\hline Normal & $7(14.3)$ & $105(47.3)$ & 18.040 & $<0.001$ \\
\hline Low & $42(85.7)$ & $117(52.7)$ & & \\
\hline DBIL & & & & \\
\hline Normal & $30(61.2)$ & $200(90.1)$ & 26.048 & $<0.001$ \\
\hline Abnormal & $19(38.8)$ & $22(9.9)$ & & \\
\hline GGT & & & & \\
\hline Normal & $30(61.2)$ & $172(77.5)$ & 5.587 & 0.018 \\
\hline Abnormal & 19 (38.8) & $50(22.5)$ & & \\
\hline LDH & & & & \\
\hline Normal & $0(0.0)$ & $60(27.0)$ & 17.009 & $<0.001$ \\
\hline Abnormal & $49(100.0)$ & $162(73.0)$ & & \\
\hline Sodium & & & & \\
\hline Normal & $26(53.1)$ & $183(82.4)$ & 29.732 & $<0.001$ \\
\hline Low & $9(18.4)$ & $28(12.6)$ & & \\
\hline High & $14(28.6)$ & $11(5.0)$ & & \\
\hline Calcium ion & & & & \\
\hline Normal & $7(14.3)$ & $95(42.8)$ & 13.898 & $<0.001$ \\
\hline Abnormal & $42(85.7)$ & $127(57.2)$ & & \\
\hline BU & & & & \\
\hline Normal & $24(49.0)$ & $145(65.3)$ & 41.100 & $<0.001$ \\
\hline Low & $1(2.0)$ & $51(23.0)$ & & \\
\hline High & $24(49.0)$ & $26(11.7)$ & & \\
\hline $\mathrm{HCO}$ & & & & \\
\hline Normal & $18(36.7)$ & $176(79.3)$ & 53.127 & $<0.001$ \\
\hline Low & $30(61.2)$ & $30(13.5)$ & & \\
\hline High & $1(2.0)$ & $16(7.2)$ & & \\
\hline eGFR & & & & \\
\hline Normal & $11(22.4)$ & $104(46.8)$ & 9.781 & 0.002 \\
\hline Abnormal & 38 (77.6) & 118 (53.2) & & \\
\hline PT & & & & \\
\hline Normal & $12(24.5)$ & $170(76.6)$ & 49.376 & $<0.001$ \\
\hline Abnormal & 37 (75.5) & $52(23.4)$ & & \\
\hline INR & & & & \\
\hline Normal & $24(49.0)$ & $194(87.4)$ & 37.638 & $<0.001$ \\
\hline Abnormal & $25(51.0)$ & $28(12.6)$ & & \\
\hline Age (year) & & & & \\
\hline$\leq 65$ & $13(26.5)$ & $110(49.5)$ & 8.581 & 0.003 \\
\hline$>65$ & 36 (73.5) & $112(50.5)$ & & \\
\hline FIB & & & & \\
\hline Normal & $18(36.7)$ & $67(30.2)$ & 14.199 & 0.001 \\
\hline Low & $6(12.2)$ & $4(1.8)$ & & \\
\hline High & $25(51.0)$ & $151(68.0)$ & & \\
\hline D-D dimer quar & & & & \\
\hline Normal & $1(2.0)$ & $59(26.6)$ & 14.018 & $<0.001$ \\
\hline Abnormal & $48(98.0)$ & $163(73.4)$ & & \\
\hline
\end{tabular}


Table 1: (Continued)

\begin{tabular}{|c|c|c|c|c|}
\hline \multirow[t]{2}{*}{ Variables } & \multicolumn{2}{|l|}{ Group (\%) } & \multirow[t]{2}{*}{$\chi^{2}$} & \multirow[t]{2}{*}{$p$-value } \\
\hline & Control $(n=49)$ & Negative conversion $(n=222)$ & & \\
\hline \multicolumn{5}{|l|}{ IL-2R } \\
\hline Normal & $4(8.2)$ & $111(50.0)$ & \multirow[t]{3}{*}{35.554} & \multirow[t]{3}{*}{$<0.001$} \\
\hline Low & $1(2.0)$ & $16(7.2)$ & & \\
\hline High & $44(89.8)$ & $95(42.8)$ & & \\
\hline \multicolumn{5}{|l|}{ IL-6 } \\
\hline Normal & $2(4.1)$ & $106(47.7)$ & \multirow[t]{2}{*}{31.930} & \multirow{2}{*}{$<0.001$} \\
\hline Abnormal & 47 (95.9) & $116(52.3)$ & & \\
\hline \multicolumn{5}{|l|}{ IL-8 } \\
\hline Normal & $35(71.4)$ & $216(97.3)$ & \multirow[t]{2}{*}{35.604} & \multirow{2}{*}{$<0.001$} \\
\hline Abnormal & $14(28.6)$ & $6(2.7)$ & & \\
\hline \multicolumn{5}{|l|}{ IL-10 } \\
\hline Normal & $19(38.8)$ & $177(79.7)$ & \multirow[t]{2}{*}{33.636} & \multirow[t]{2}{*}{$<0.001$} \\
\hline Abnormal & $30(61.2)$ & $45(20.3)$ & & \\
\hline
\end{tabular}

UPRO: Urine protein; P: positive; N: Negative; U-KET: urine ket; URO: Urobilinogen; WBC: white blood cell count (normal: 3.50-9.50 low: $<3.50$ high: $\left.>9.50,10^{\circ} / \mathrm{L}\right)$; NEUT: neutrophil count (normal: $1.80-6.30$ low: $<1.80$ hign: $>6.30,10^{9} /$ L); LC: lymphocyte count (normal: $1.10-3.20$ abnotma: PCT: Procalcitonin (normal: 0.02-0.05 high: $\geq 0.05, \mathrm{ng} / \mathrm{mL}$ ); Hypersensitive cardiac troponin (normal: $\leq 34.2 / 15.6$ (male/female) high: $>34.2 / 15.6$ (male/female), pg/mL); AST: Glutamic oxalacetic transaminase (normal: $\leq 40 / 32$
(male/female) high: $>40 / 32$ (male/female) U/L); TP: Total protein (normal: $64-83$ abnormal: $<64$ or $>83$, g/L); Albumin (normal: $35-52$ low: $<35$, g/L); DBIL: Direct bilirubin (normal: $\leq 8.0$ abnormal: $>8.0, \mu$ mol/L); GGT: Gammaglutamyl transpeptidase (normal: 10/6-71/42 (male/female) abnormal: <10/6 or >71/42 (male/female), U/L); LDH: Lactic dehydrogenase (normal: $135-225 / 214$ (male/female) abnormal: $<135$ or $>225 / 214$ (male/female), U/L); Sodium (normal: 136-145 low: <136 high: >145, mmol/L); Calcium ion (normal: 2.20-2.55 abnormal: <2.20 or >2.55, mmol/L); BU: Blood urea (normal: $3.6 / 3.1-9.5 / 8.8$ (male/female) low: <3.6/3.1 (male/female) high: $>9.5 / 8.8$ (male/female), mmol/L); HCO: Bicarbonate radical (normal: 22.0-29.0 low: $<22.0$ high: $>29.0, \mathrm{mmol} / \mathrm{L}$ ); eGFR: Epidermal growth factor receptor (normal: $>90$ abnormal: $\leq 90, \mathrm{~mL} / \mathrm{min} / 1.73 \mathrm{~m}^{2}$ ); PT: Prothrombin time (normal: 11.5-14.5 abnormal: $<11.5$ or >14.5,s); INR: International normalized ratio (normal: $0.80-1.20$ abnormal: $>1.20$ ); FIB: Fibrinogen (normal: $2.00-4.00$ low: $<2.00$ high: $>4.00$, g/L); D-D dimer quantification (normal: $<0.5$ abnormal: $\geq 0.5, \mu \mathrm{g} / \mathrm{mL}$ FEU); LL-2R: Interleukin-2 receptor (normal: 223-710 low: $<223$ high: $>710, \mathrm{U} / \mathrm{mL}$ ); LL-6: Interleukin 6 (normal: $<7.0$ abnormal: $\geq 7.0$, pg/mL); IL-8: Interleukin 8 (normal: <62 abnormal: $\geq 62$, pg/mL);

IL-10: Interleukin 10 (normal: $<9.1$ abnormal: $\geq 9.1, \mathrm{pg} / \mathrm{mL}$ ).

Table 2: Collinearity diagnostics results

\begin{tabular}{lll}
\hline Model & \multicolumn{2}{l}{ Collinearity statistics } \\
\cline { 2 - 3 } & Tolerance & VIF \\
\hline Age & 0.492 & 2.032 \\
WBC & 0.567 & 1.765 \\
LC & 0.523 & 1.911 \\
NT-PROBNP & 0.483 & 2.070 \\
Hypersensitive cardiac troponin & 0.540 & 1.851 \\
TP & 0.244 & 4.105 \\
DBIL & 0.617 & 1.621 \\
GGT & 0.826 & 1.211 \\
LDH & 0.169 & 5.903 \\
Sodium & 0.159 & 6.270 \\
Calcium ion & 0.026 & 38.389 \\
HCO & 0.037 & 27.243 \\
PT & 0.528 & 1.893 \\
INR & 0.954 & 1.048 \\
FIB & 0.608 & 1.644 \\
D-D dimer quantification & 0.513 & 1.948 \\
IL-2R & 0.374 & 2.676 \\
IL-6 & 0.028 & 35.273 \\
NEUT & 0.444 & 2.252 \\
PCT & 0.045 & 22.313 \\
AST & 0.096 & 10.420 \\
Albumin & 0.319 & 3.139 \\
BU & 0.205 & 4.879 \\
eGFR & 0.236 & 4.234 \\
IL-8 & 0.030 & 33.805 \\
IL-10 & 0.109 & 9.157 \\
\hline WBC: Wh
\end{tabular}

WBC: White blood cell count; LC: Lymphocyte count; NT-PROBNP: Amino-terminal pro-brain natriuretic peptide; TP: Total protein; DBIL: Direct bilirubin; GGT: Gamma-glutamyl transpeptidase; LDH: Lactic dehydrogenase; HCO: Bicarbonate radical; PT: Prothrombin time; INR: International normalized ratio; FIB: Fibrinogen; IL-2R: Interleukin-2 receptor 2; IL-6: Interleukin 6; NEUT: Neutrophil count; PCT: procalcitonin; AST: Glutamic oxalacetic transaminase; BU: Blood urea;; eGFR: Epidermal growth factor receptor; IL-8: Interleukin 8; IL-10: Interleukin 10.

Table 3: Collinearity diagnostics after adjusting variables

\begin{tabular}{lll}
\hline Model & \multicolumn{2}{l}{ Collinearity statistics } \\
\cline { 2 - 3 } & Tolerance & VIF \\
\hline Age & 0.712 & 1.404 \\
WBT & 0.599 & 1.670 \\
LC & 0.542 & 1.845 \\
NT-PROBNP & 0.789 & 1.267 \\
Hypersensitive cardiac troponin & 0.620 & 1.614 \\
TP & 0.319 & 3.132 \\
DBIL & 0.689 & 1.450 \\
GGT & 0.921 & 1.086 \\
LDH & 0.356 & 2.808 \\
Sodium & 0.428 & 2.336 \\
PT & 0.549 & 1.823 \\
INR & 0.970 & 1.031 \\
FIB & 0.710 & 1.409 \\
D-D dimer quantification & 0.555 & 1.801 \\
IL-2R & 0.474 & 2.109 \\
NEUT & 0.467 & 2.140 \\
Albumin & 0.358 & 2.793 \\
IL-10 & 0.643 & 1.556 \\
\hline WBC: White blood cell count: LC: Lymphocyte count; NT-PROBNP. Amino-terminal pro-brain natriuretic
\end{tabular}

WBC: White blood cell count; LC: Lymphocyte count; NT-PROBNP: Amino-terminal pro-brain natriuretic peptide; TP: Total protein; DBIL: Direct bilirubin; GGT: Gamma-glutamyl transpeptidase; LDH: Lactic dehydrogenase; PT: Prothrombin time; INR: International normalized ratio; FIB: Fibrinogen; IL-2R: Interleukin-receptor 2; NEUT: Neutrophil count; IL-10: Interleukin 10.

\section{Multivariate analysis results}

The variables whose $p<0.05$ in a single factor analysis and whose missing values were filled were included in Cox regression analysis, the method was forward: LR, with inclusion criteria of 0.05 and exclusion criteria of 0.10 . We found that lactic dehydrogenase $(\mathrm{LDH})$, age, fibrinogen (FIB), and disease severity were associated with delayed clearance of viral RNA in patients, as shown in Table 4. Then, drew the Kaplan and Meier curves and performed Log Rank test, as shown in Figures 1-4.

Table 4: Multivariate analysis results

\begin{tabular}{llllllll}
\hline Variables & $\mathrm{B}$ & $\mathrm{SE}$ & Wald & df & p-value & $\mathrm{HR}$ & $95.0 \% \mathrm{Cl}$ for HR \\
\hline Age & -0.302 & 0.137 & 4.824 & 1 & 0.028 & 0.739 & $(0.565,0.968)$ \\
Disease severity & -1.111 & 0.172 & 41.540 & 1 & 0.000 & 0.329 & $(0.235,0.462)$ \\
FIB normal & & & 19.555 & 2 & 0.000 & & \\
Low & -0.657 & 0.530 & 1.537 & 1 & 0.215 & 0.519 & $(0.184,1.465)$ \\
High & -0.715 & 0.162 & 19.406 & 1 & 0.000 & 0.489 & $(0.356,0.672)$ \\
LDH & -0.532 & 0.161 & 10.952 & 1 & 0.001 & 0.587 & $(0.428,0.805)$ \\
\hline
\end{tabular}

FIB: Fibrinogen (normal: $2.00-4.00$ low: $<2.00$ high: $>4.00$, g/L); LDH: Lactic dehydrogenase.

\section{Discussion}

We found that on the whole, men were less likely than women to undergo negative conversion of SARS-CoV-2 RNA ( $p<0.05)$, which was consist with some other studies to some extent [13], [14], [15]. However, in our study, univariate Cox regression showed that gender was not related factor, so we did not include it. By the end of observation, the median duration of virus in the control group was 24 days that in the negative conversion group was 17 days; the difference was statistically significant $(p<0.05)$. It is very important to study the factors related to the negative transformation of the virus to shorten the duration of the virus and eliminate the virus in the body as soon as possible.

In our study, multivariate Cox regression showed that age was a relevant factor for viral nucleic 


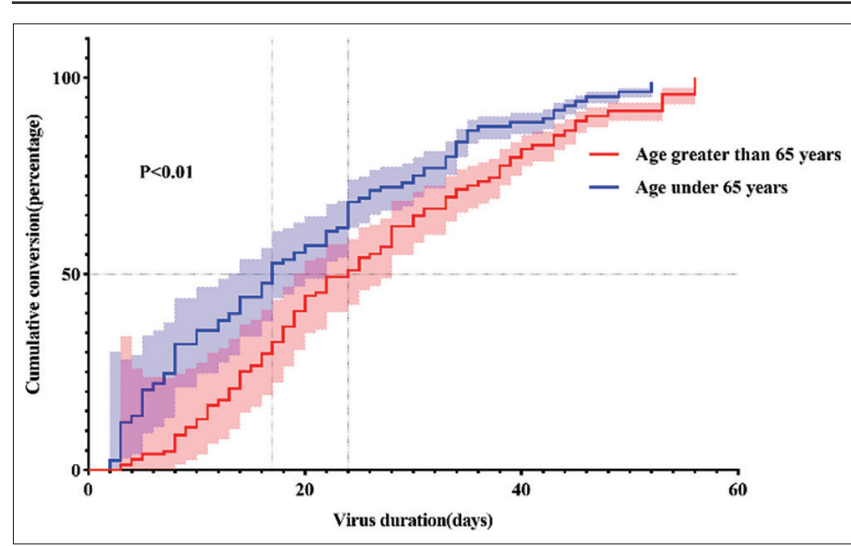

Figure 1: Negative conversion curves in coronavirus disease-19 patients according to age

acid negative transformation, and those younger than 65 years were more likely to have negative conversion than those older than 65 years $(\mathrm{HR}=0.739, \mathrm{p}<0.05)$.

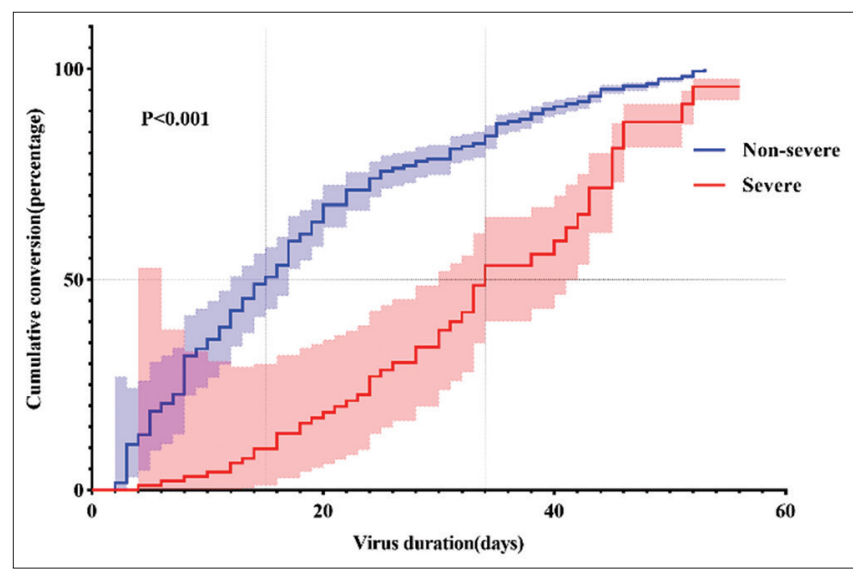

Figure 2: Negative conversion curves in coronavirus disease-19 patients according to disease severity

When the cutoff for age was set at 45 years as a related study did [16], we did not find this difference between the two age groups.

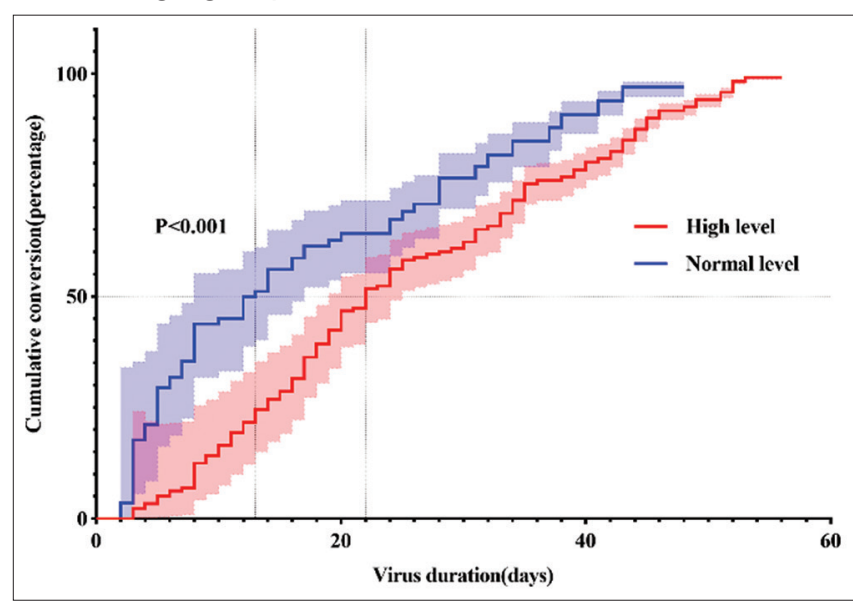

Figure 3: Negative conversion curves in coronavirus disease-19 patients according to fibrinogen

So we set the cutoff at 65 years as another research did [17] and found age > 65 years was a factor associated with viral negative conversion. First, older patients have a poorer prognosis as some studies showed [18], [19], [20]. Then, elderly patients are prone to systemic complications that may affect the clearance of SARS-CoV-2 [21]. In addition, it is generally believed that with age, immune system becomes weaker. Therefore, the risk of infection increases and the virus is difficult to remove from the body [22], [23].

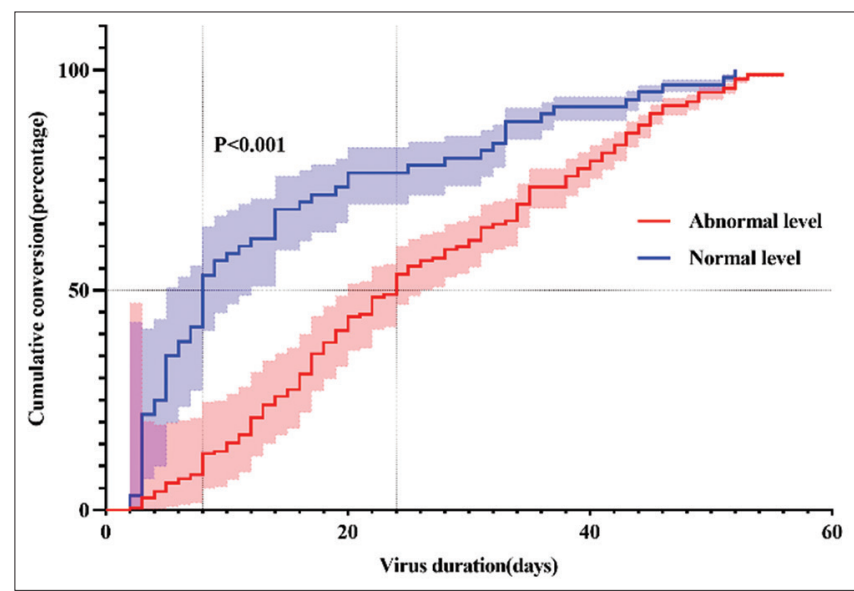

Figure 4: Negative conversion curves in coronavirus disease-19 patients according to lactic dehydrogenase

We found that the clearance of SARS-CoV-2 was associated with disease severity. It will be less conducive to virus removal if the illness at the time of admission is more serious. Ding Shi and other researchers have proved the same result [17]. The consensus view is that having severe COVID-19 symptoms affects the prognosis. As we all know, the more serious the disease is, the more critical complications may happen, which may affect the clearance of the virus in the body [24], [25].

Early studies have suggested that COVID-19 patients were easy to present with coagulopathy, disseminated intravascular coagulation, and other complications [26], [27], [28]. Based on this finding, our study has demonstrated that high levels of FIB were related to the delayed virus clearance. Although few studies have been consistent with our results, some researchers have confirmed that FIB seems to increase early in COVID19 patients or severe patients and may be used as a risk stratification marker [29], [30]. As for the mechanism of clotting disorder, according to relative research, the endothelial glycocalyx is one of the important targets in the pathogenesis of virus-induced coagulopathy, while it still remains to be clarified whether similar mechanisms exist in COVID-19 or not. Besides, in a severer viral infection, both direct virus-induced cytotoxic effect and indirect injury may damage the host, pro-inflammatory cytokines and chemokines reported in COVID-19 were examples [31], [32]. For coagulation disorders, the corresponding treatment may indirectly help the virus to turn negative so as to improve the prognosis.

Meta-analysis showed that the laboratory indicator abnormality that COVID-19 patients were more likely to occur was the elevated LDH level and it had stronger correlations with COVID-19 mortality [20], [33]. In other studies, patients were divided into the severe group with diabetes and the group without diabetes, the 
cardiovascular disease group and the non-cardiovascular disease group. The results showed that the level of LDH in the former group was higher than that in the control group, which indicates the increase of LDH may be associated with cooccurring chronic diseases. These patients were more likely to suffer from multiple organ dysfunction syndrome [6], [34]. It has been reported that the cause of elevated LDH may be that the virus damages muscles and myocardial [35]. Increased LDH may cause the decrease of cytosolic $\mathrm{pH}$ and exacerbate muscle soreness [36]. Therefore, it is necessary to detect the LDH concentration in time and to determine the degree of damage to important organs in the body.

We studied the related factors from the perspective of virus negative conversion. It has been rarely studied in the previous research. In addition, variables with missing values greater than $20 \%$ were eliminated and other missing values were filled to ensure the stability of multi-factor analysis results. However, this study still has some shortcomings. Factors that may affect the lab indicators, such as comorbidities, were not included in the analysis because of the excessive lack of data and the causal relationship between laboratory findings and disease severity could not be determined.

\section{Conclusion}

Our study found that age older than 65 years, more severe disease; the elevated levels of LDH and FIB were not conducive to the negative conversion of SARS-CoV-2 RNA. Under the same conditions, the elevated group would prolong the virus clearance time. Therefore, in the treatment of COVID-19, attention should be paid to people over 65 years old and in critical condition and monitor these indicators, so as to control the inflammation and organ damage caused by viral infection, and help to improve the prognosis of patients.

\section{Acknowledgments}

The authors are grateful to all health workers. The authors also would like to thank Mr. Zhonghua Zheng for his assistance in language polishing, journal selecting, and formatting of this manuscript.

\section{References}

1. Zhu N, Zhang D, Wang W, Li X, Yang B, Song J, et al. A Novel coronavirus from patients with pneumonia in China, 2019.
N Engl J Med. 2020;382(8):727-33. https://doi.org/10.1056/ NEJMoa2001017

PMid: 31978945

2. Shi Y, Wang G, Cai XP, Deng JW, Zheng L, Zhu HH, et al. An overview of COVID-19. J Zhejiang Univ Sci B. 2020;21(5):34360. https://doi.org/10.1631/jzus.B2000083

PMid: 32425000

3. Zhai P, Ding Y, Wu X, Long J, Zhong Y, Li Y. The epidemiology, diagnosis and treatment of COVID-19. Int $\mathrm{J}$ Antimicrob Agents. 2020;55(5):105955. https://doi.org/10.1016/j. ijantimicag.2020.105955

PMid: 32234468

4. Vankadari N, Wilce JA. Emerging WuHan (COVID-19) coronavirus: Glycan shield and structure prediction of spike glycoprotein and its interaction with human CD26. Emerg Microbes Infect. 2020;9(1):601-4. https://doi.org/10.1080/2222 1751.2020.1739565

PMid:32178593

5. Fu Y, Han P, Zhu R, Bai T, Yi J, Zhao X, et al. Risk factors for viral RNA shedding in COVID-19 patients. Eur Respir J. 2020;56(1):2001190. https://doi. org/10.1183/13993003.01190-2020 PMid:32398298

6. Yan $\mathrm{Y}$, Yang $\mathrm{Y}$, Wang $\mathrm{F}$, Ren $\mathrm{H}$, Zhang $\mathrm{S}$, Shi $\mathrm{X}$, et al. Clinical characteristics and outcomes of patients with severe covid-19 with diabetes. BMJ Open Diabetes Res Care. 2020;8(1):1343. https://doi.org/10.1136/bmjdrc-2020-001343 PMid:32345579

7. Magro G. SARS-CoV-2 and COVID-19: Is interleukin-6 (IL6) the "culprit lesion" of ARDS onset? What is there besides tocilizumab? SGP130Fc. Cytokine X. 2020;14:100029. https:// doi.org/10.1016/j.cytox.2020.100029

PMid:32421092

8. Wang F, Yang Y, Dong K, Yan Y, Zhang S, Ren H, et al. Clinica characteristics of 28 patients with diabetes and covid-19 in Wuhan, China. Endocr Pract. 2020;26(6):668-74. https://doi. org/10.4158/EP-2020-0108

PMid: 32357072

9. Liu B, Li M, Zhou Z, Guan X, Xiang Y. Can we use interleukin-6 (IL-6) blockade for coronavirus disease 2019 (COVID-19)induced cytokine release syndrome (CRS)? J Autoimmun. 2020;111:102452. https://doi.org/10.1016/j.jaut.2020.102452 PMid:32291137

10. Arnaldez FI, O'Day SJ, Drake CG, Fox BA, Fu B, Urba WJ et al. The society for immunotherapy of cancer perspective on regulation of interleukin-6 signaling in COVID-19-related systemic inflammatory response. J Immunother Cancer. 2020;8(1):930. https://doi.org/10.1136/jitc-2020-000930 PMid:32385146

11. Lagunas-Rangel FA, Chávez-Valencia V. High IL-6/IFN- $\gamma$ ratio could be associated with severe disease in COVID-19 patients. J Med Virol. 2020;10:25900. https://doi.org/10.1002/jmv.25900 PMid:32297995

12. Zhang $X$, Tan $Y$, Ling $Y$, Lu G, Liu F, Yi Z, et al. Viral and host factors related to the clinical outcome of COVID-19. Nature. 2020;583(7816):437-40. https://doi.org/10.1038/ s41586-020-2355-0 PMid:32434211

13. Gebhard C, Regitz-Zagrosek V, Neuhauser HK, Morgan R, Klein SL. Impact of sex and gender on COVID-19 outcomes in Europe. Biol Sex Differ. 2020;11(1):29. https://doi.org/10.1186/ s13293-020-00304-9

PMid:32450906

14. Penna C, Mercurio V, Tocchetti CG, Pagliaro P 
Sex-related differences in COVID-19 lethality. Br J Pharmacol. 2020;177(19):4375-85. https://doi.org/10.1111/bph.15207 PMid:32698249

15. Dana PM, Sadoughi F, Hallajzadeh J, Asemi Z, Mansournia MA Yousefi B, et al. An insight into the sex differences in COVID-19 patients: What are the possible causes? Prehosp Disaster Med. 2020;35(4):438-41. https://doi.org/10.1017/S1049023X20000837 PMid:32600476

16. Hu X, Xing Y, Jia J, Ni W, Liang J, Zhao D, et al. Factors associated with negative conversion of viral RNA in patients hospitalized with COVID-19. Sci Total Environ. 2020;728:138812. https://doi. org/10.1016/j.scitotenv.2020.138812

PMid:32335406

17. Shi $\mathrm{D}, \mathrm{Wu}$ W, Wang $\mathrm{Q}, \mathrm{Xu} \mathrm{K}, \mathrm{Xie} \mathrm{J}, \mathrm{Wu} \mathrm{J}$, et al. Clinical characteristics and factors associated with long-term viral excretion in patients with SARS-CoV-2 infection: A single center 28-day study. J Infect Dis. 2020;222(6):910-8. https://doi. org/10.1093/infdis/jiaa388

PMid:32614392

18. Zhang JJ, Dong $X$, Cao YY, Yuan YD, Yang YB, Yan YQ, et al. Clinical characteristics of 140 patients infected with SARSCoV-2 in Wuhan, China. Allergy. 2020;75(7):1730-41. https:// doi.org/10.1111/all.14238

PMid:32077115

19. Shi $Q$, Zhang $X$, Jiang $F$, Zhang $X$, Hu N, Bimu C, et al. Clinical characteristics and risk factors for mortality of COVID19 patients with diabetes in Wuhan, China: A two-center, retrospective study. Diabetes Care. 2020;43(7):1382-91. https:// doi.org/10.2337/dc20-0598 PMid:32409504

20. Li X, Xu S, Yu M, Wang K, Tao Y, Zhou Y, et al. Risk factors for severity and mortality in adult COVID-19 inpatients in Wuhan. J Allergy Clin Immunol. 2020;146(1):110-8. https://doi. org/10.1016/j.jaci.2020.04.006 PMid:32294485

21. Liu K, Chen Y, Lin R, Han K. Clinical features of COVID-19 in elderly patients: A comparison with young and middle-aged patients. J Infect. 2020;80(6):e14-8. https://doi.org/10.1016/j. jinf.2020.03.005

PMid:32171866

22. Grubeck-Loebenstein B, Wick G. The aging of the immune system. Adv Immunol. 2002;80:243-84. https://doi.org/10.1016/ s0065-2776(02)80017-7

PMid: 12078483

23. Weksler ME. Changes in the B-cell repertoire with age. Vaccine. 2000;18(16):1624-8. https://doi.org/10.1016/ s0264-410x(99)00497-1 PMid:10689139

24. Chen T, Wu D, Chen H, Yan W, Yang D, Chen G, et al. Clinical characteristics of 113 deceased patients with coronavirus disease 2019: Retrospective study. BMJ. 2020;368:m1091. https://doi.org/10.1136/bmj.m1091 PMid:32217556

25. Zhang J, Wang X, Jia X, Li J, Hu K, Chen G, et al. Risk factors for disease severity, unimprovement, and mortality in COVID-19 patients in Wuhan, China. Clin Microbiol Infect.
2020;26(6):767-72. https://doi.org/10.1016/j.cmi.2020.04.012 PMid:32304745

26. Terpos E, Ntanasis-Stathopoulos I, Elalamy I, Kastritis E, Sergentanis TN, Politou M, et al. Hematological findings and complications of COVID-19. Am J Hematol. 2020;95(7):834-47. https://doi.org/10.1002/ajh.25829

PMid:32282949

27. Connors JM, Levy JH. COVID-19 and its implications for thrombosis and anticoagulation. Blood. 2020;135(23):2033-40. https://doi.org/10.1182/blood.2020006000

PMid:32339221

28. Iba T, Levy JH, Levi M, Thachil J. Coagulopathy in COVID19. J Thromb Haemost. 2020;1:14975. https://doi.org/10.1111/ jth. 14975

PMid:32558075

29. Di Micco P, Russo V, Carannante N, Imparato M, Rodolfi S, Cardillo G, et al. Clotting factors in COVID-19: Epidemiological association and prognostic values in different clinical presentations in an Italian cohort. J Clin Med. 2020;9(5):1371. https://doi.org/10.3390/jcm9051371

PMid:32392741

30. Gao Y, Li T, Han M, Li X, Wu D, Xu Y, et al. Diagnostic utility of clinical laboratory data determinations for patients with the severe COVID-19. J Med Virol. 2020;92(7):791-6. https://doi. org/10.1002/jmv.25770

PMid:32181911

31. Huang $\mathrm{C}$, Wang $\mathrm{Y}, \mathrm{Li} X$, Ren L, Zhao J, Hu Y, et al. Clinical features of patients infected with 2019 novel coronavirus in Wuhan, China. Lancet. 2020;395(10223):497-506. https://doi. org/10.1016/S0140-6736(20)30183-5 PMid:31986264

32. Li Y, Deng W, Xiong H, Li H, Chen Z, Nie Y, et al. Immunerelated factors associated with pneumonia in 127 children with coronavirus disease 2019 in Wuhan. Pediatr Pulmonol. 2020;1:24907. https://doi.org/10.1002/ppul.24907 PMid:32543756

33. Lu L, Zhong W, Bian Z, Li Z, Zhang K, Liang B, et al. A comparison of mortality-related risk factors of COVID-19, SARS and MERS: A systematic review and meta-analysis. J Infect. 2020;81(4):e18-25. https://doi.org/10.1016/j.jinf.2020.07.002 PMid:32634459

34. Li M, Dong $\mathrm{Y}$, Wang $\mathrm{H}$, Guo $\mathrm{W}$, Zhou $\mathrm{H}$, Zhang $\mathrm{Z}$, et al. Cardiovascular disease potentially contributes to the progression and poor prognosis of COVID-19. Nutr Metab Cardiovasc Dis. 2020;30(7):1061-7. https://doi.org/10.1016/j.numecd.2020.04.013 PMid:32456948

35. Li L, Zhang S, He B, Chen X, Zhao Q. Retrospective study of risk factors for myocardial damage in patients with critical coronavirus disease 2019 in Wuhan. J Am Heart Assoc. 2020;9(15):e016706. https://doi.org/10.1161/JAHA.120.016706 PMid:32600078

36. Kucuk A, Cure MC, Cure E. Can COVID-19 cause myalgia with a completely different mechanism? A hypothesis. Clin Rheumatol. 2020;39(7):2103-4. https://doi.org/10.1007/ s10067-020-05178-1

PMid:32458242 